\title{
p53 codon 72 polymorphism and breast cancer risk: A meta-analysis
}

\author{
JING HOU $^{1}$, YUAN JIANG ${ }^{1}$, WENRU TANG ${ }^{2}$ and SHUTING JIA ${ }^{2}$ \\ ${ }^{1}$ Laboratory of Molecular Genetics of Aging and Tumor, Medical Faculty; \\ ${ }^{2}$ Laboratory of Molecular Genetics of Aging and Tumor, Faculty of Life Science and Technology, \\ Kunming University of Science and Technology, Kunming, Yunnan 650500, P.R. China
}

Received January 4, 2013; Accepted March 12, 2013

DOI: $10.3892 /$ etm.2013.1019

\begin{abstract}
. p53 is a tumor suppressor gene and plays important roles in the etiology of breast cancer. Studies have produced conflicting results concerning the role of p53 codon 72 polymorphism $(\mathrm{G}>\mathrm{C})$ on the risk of breast cancer; therefore, a meta-analysis was performed to estimate the association between the p53 codon 72 polymorphism and breast cancer. Screening of the PubMed database was conducted to identify relevant studies. Studies containing available genotype frequencies of the p53 codon 72 polymorphism were selected and a pooled odds ratio (OR) with $95 \%$ confidence interval (CI) was used to assess the association. Sixty-one published studies, including 28,539 breast cancer patients and 32,788 controls were identified. The results suggest that variant genotypes are not associated with breast cancer risk (Pro/Pro + Arg/Pro vs. Arg/Arg: $\mathrm{OR}=1.016,95 \% \mathrm{CI}=0.931-1.11, \mathrm{P}=0.722)$. The symmetric funnel plot, Egger's test $(\mathrm{P}=0.506)$ and Begg's test $(\mathrm{P}=0.921)$ were all suggestive of the lack of publication bias. This meta-analysis suggests that the p53 codon 72 Pro/Pro + Arg/Pro genotypes are not associated with an increased risk of breast cancer. To validate the association between the p53 codon 72 polymorphism and breast cancer, further studies with larger numbers of participants worldwide are required.
\end{abstract}

\section{Introduction}

Breast cancer is one of the most common cancers affecting the morbidity and mortality of females worldwide (1). While numerous risk factors for breast cancer have been identified, including genetic predisposition and estrogen level, the

Correspondence to: Dr Shuting Jia or Dr Wenru Tang, Laboratory of Molecular Genetics of Aging and Tumor, Faculty of Life Science and Technology, Kunming University of Science and Technology, 727 Jing Ming Nan Road, Chenggong, Kunming, Yunnan 650500, P.R. China

E-mail: lilith-jia@hotmail.com

E-mail:twr@sina.com

Key words: p53, meta-analysis, breast cancer molecular mechanisms related to breast carcinogenesis remain under analysis $(2,3)$. Previous studies have shown alterations in cell cycle regulatory proteins in breast carcinoma, including the overexpression and increase of the cyclin genes, inactivation and deletions of the $\mathrm{Rb}$ gene and alterations of the p53 gene (4-6). Therefore, this disease is a result of collective alterations of oncogenes and tumor suppressor genes. It is well-known that $\mathrm{p} 53$, the guardian of the genome, is a stress response protein. $\mathrm{p} 53$ functions mainly as a tetramer transcription factor that regulates a large number of genes in response to various stresses, including ontogeny activation and DNA damage (7). p53 is involved in the pro-survival response of cell cycle arrest and DNA damage repair, as well as the pro-death response of apoptosis (8). In the case of a mutation occurring in the p53 gene, p53 may not only lose its normal functions, but also gain new abilities that promote tumorigenesis (9). p53 is the most frequently mutated gene in human tumors; $>50 \%$ of tumors harbor mutations in the p53 gene (10). Besides its role as a tumor suppressor gene, aberrant p53 expression may play a significant role in regulating angiogenesis $(11,12)$. Chromosomal aberrations and p53 protein abnormalities may be involved in malignant transformation of endometriosis in the ovary (13).

The p53 tumor suppressor gene contains 11 exons, located on chromosome $17 \mathrm{p} 13$. The codon 72 polymorphism (rs1042522) is located in exon 4 with a CGC to CCC transition, leading to an arginine to proline amino acid substitution in amino acid position 72 (Arg72Pro). Studies have reported that the codon 72 polymorphism is associated with a risk for the development of cancer (14). The two polymorphic variants have been shown to have not only structural differences, as reflected by distinct electrophoresis patterns of migration, but also different biological properties $(15,16)$. A number of casecontrol studies have been conducted to explore the correlation between the p53 codon 72 polymorphism and breast cancer risk in humans. However, the results are inconsistent. Another problem is that these published studies have only modest sample sizes, which limits their significance. By performing a meta-analysis, a prevailing method for the quantitative summary of different results, the data may be assessed and the sample size increased to a reasonable level. In the present study, a meta-analysis was conducted to quantitatively assess the effect of the p53 codon 72 polymorphism on the risk of breast cancer. 
Table I. Distribution of the p53 codon 72 polymorphism for cases and controls.

\begin{tabular}{|c|c|c|c|c|c|c|c|c|c|}
\hline \multirow[b]{2}{*}{ Population } & \multirow[b]{2}{*}{ First author (ref) } & \multirow[b]{2}{*}{ Year } & \multicolumn{3}{|c|}{ Breast cancer } & \multicolumn{3}{|c|}{ Control } & \multirow[b]{2}{*}{ P-value } \\
\hline & & & Arg/Arg & Arg/Pro & Pro/Pro & Arg/Arg & Arg/Pro & Pro/Pro & \\
\hline \multirow[t]{20}{*}{ Asian } & Kawajiri (40) & 1993 & 5 & 51 & 37 & 38 & 165 & 144 & 0.36 \\
\hline & Khaliq (41) & 2000 & 13 & 18 & 10 & 177 & 321 & 191 & 0.08 \\
\hline & $\operatorname{Li}(30)$ & 2002 & 6 & 11 & 11 & 14 & 26 & 10 & 0.74 \\
\hline & Huang (28) & 2003 & 36 & 100 & 64 & 30 & 138 & 114 & 0.21 \\
\hline & Katiyar (29) & 2003 & 6 & 51 & 20 & 8 & 24 & 9 & 0.27 \\
\hline & Mahasneh (42) & 2004 & 8 & 19 & 16 & 29 & 51 & 56 & 0.01 \\
\hline & Noma (43) & 2004 & 29 & 69 & 93 & 31 & 76 & 111 & 0.00 \\
\hline & Siddique (44) & 2005 & 20 & 38 & 36 & 38 & 120 & 107 & 0.64 \\
\hline & Мa (45) & 2006 & 77 & 178 & 149 & 100 & 222 & 150 & 0.29 \\
\hline & Gochhait (26) & 2007 & 48 & 109 & 86 & 97 & 160 & 76 & 0.52 \\
\hline & Khadang (37) & 2007 & 29 & 109 & 83 & 40 & 90 & 75 & 0.17 \\
\hline & Rajkumar (46) & 2008 & 59 & 125 & 66 & 141 & 224 & 135 & 0.02 \\
\hline & Zhang (34) & 2007 & 17 & 45 & 21 & 33 & 87 & 47 & 0.52 \\
\hline & Lum (47) & 2008 & 88 & 200 & 105 & 13 & 38 & 29 & 0.93 \\
\hline & Singh (48) & 2008 & 13 & 45 & 46 & 12 & 64 & 29 & 0.01 \\
\hline & Kazemi (49) & 2009 & 6 & 30 & 6 & 0 & 45 & 12 & 0.00 \\
\hline & Song (50) & 2009 & 221 & 544 & 339 & 220 & 508 & 349 & 0.16 \\
\hline & Koh (51) & 2011 & 102 & 197 & 73 & 179 & 319 & 145 & 0.90 \\
\hline & Kara (52) & 2010 & 105 & 84 & 14 & 72 & 80 & 17 & 0.44 \\
\hline & Leu (53) & 2011 & 71 & 90 & 78 & 104 & 129 & 88 & 0.00 \\
\hline \multirow[t]{30}{*}{ Caucasian } & Själander (22) & 1996 & 24 & 93 & 95 & 61 & 253 & 375 & 0.06 \\
\hline & Weston (33) & 1997 & 6 & 27 & 32 & 3 & 42 & 72 & 0.28 \\
\hline & Wang-Gohrke (54) & 1998 & 5 & 46 & 56 & 21 & 117 & 167 & 0.93 \\
\hline & Papadakis (55) & 2000 & 12 & 10 & 34 & 6 & 41 & 12 & 0.00 \\
\hline & Wang-Gohrke (32) & 2002 & 49 & 221 & 282 & 40 & 203 & 300 & 0.49 \\
\hline & Buyru (25) & 2003 & 12 & 39 & 64 & 12 & 43 & 21 & 0.20 \\
\hline & Suspitsin (56) & 2003 & 42 & 203 & 284 & 27 & 159 & 207 & 0.63 \\
\hline & Menzel (57) & 2004 & 30 & 170 & 275 & 30 & 114 & 158 & 0.17 \\
\hline & Kalemi (23) & 2005 & 3 & 13 & 26 & 9 & 32 & 10 & 0.07 \\
\hline & Ohayon (58) & 2005 & 3 & 40 & 89 & 19 & 94 & 54 & 0.02 \\
\hline & Tommiska (39) & 2005 & 109 & 617 & 825 & 52 & 278 & 403 & 0.67 \\
\hline & Baynes (35) & 2007 & 148 & 768 & 1107 & 166 & 854 & 1177 & 0.52 \\
\hline & Garcia-Closas (59) & 2007 & 196 & 1021 & 1368 & 228 & 1249 & 1774 & 0.69 \\
\hline & Franeková (60) & 2007 & 8 & 34 & 49 & 9 & 55 & 92 & 0.84 \\
\hline & Johnson (61) & 2007 & 30 & 185 & 257 & 183 & 925 & 1354 & 0.15 \\
\hline & Schmidt (38) & 2007 & 618 & 3228 & 4499 & 511 & 2677 & 3661 & 0.48 \\
\hline & Sprague (31) & 2007 & 100 & 644 & 909 & 129 & 704 & 1021 & 0.61 \\
\hline & Akkiprik (24) & 2009 & 20 & 50 & 25 & 12 & 49 & 46 & 0.85 \\
\hline & Cavallone (62) & 2008 & 10 & 67 & 80 & 9 & 46 & 57 & 0.95 \\
\hline & Costa (63) & 2008 & 25 & 86 & 137 & 54 & 212 & 380 & 0.00 \\
\hline & De Vecchi (64) & 2008 & 15 & 150 & 185 & 14 & 131 & 207 & 0.23 \\
\hline & Nordgard (65) & 2008 & 5 & 58 & 46 & 14 & 34 & 73 & 0.00 \\
\hline & Lång (66) & 2009 & 6 & 45 & 65 & 5 & 58 & 79 & 0.15 \\
\hline & Denisov (77) & 2009 & 25 & 124 & 148 & 29 & 99 & 147 & 0.05 \\
\hline & Henríquez (27) & 2009 & 8 & 54 & 73 & 28 & 100 & 167 & 0.03 \\
\hline & Hrstka (68) & 2009 & 40 & 15 & 62 & 45 & 8 & 55 & 0.00 \\
\hline & Bisof (69) & 2010 & 11 & 23 & 61 & 5 & 42 & 61 & 0.51 \\
\hline & Ebner (70) & 2010 & 17 & 108 & 138 & 14 & 103 & 137 & 0.34 \\
\hline & Kara (52) & 2010 & 14 & 84 & 105 & 17 & 80 & 72 & 0.44 \\
\hline & Alshatwi (71) & 2012 & 22 & 52 & 26 & 32 & 51 & 17 & 0.66 \\
\hline
\end{tabular}


Table I continued.

\begin{tabular}{|c|c|c|c|c|c|c|c|c|c|}
\hline \multirow[b]{2}{*}{ Population } & \multirow[b]{2}{*}{ First author } & \multirow[b]{2}{*}{ Year } & \multicolumn{3}{|c|}{ Breast cancer } & \multicolumn{3}{|c|}{ Control } & \multirow[b]{2}{*}{ P-value ${ }^{a}$} \\
\hline & & & Arg/Arg & Arg/Pro & Pro/Pro & Arg/Arg & Arg/Pro & Pro/Pro & \\
\hline & Alawadi (72) & 2011 & 81 & 200 & 7 & 50 & 112 & 26 & 0.00 \\
\hline \multirow{8}{*}{ Others } & Weston (33) & 1997 & 1 & 9 & 6 & 4 & 14 & 12 & 0.98 \\
\hline & Weston (73) & 1994 & 7 & 8 & 3 & 12 & 16 & 10 & 0.34 \\
\hline & Helland (74) & 1998 & 6 & 40 & 63 & 13 & 90 & 122 & 0.50 \\
\hline & Mabrouk (36) & 2003 & 3 & 9 & 18 & 4 & 26 & 19 & 0.23 \\
\hline & $\operatorname{Damin}(21)$ & 2006 & 64 & 48 & 6 & 70 & 111 & 21 & 0.02 \\
\hline & Cox (75) & 2007 & 104 & 569 & 804 & 131 & 838 & 1255 & 0.57 \\
\hline & Gaudet (76) & 2008 & 46 & 244 & 288 & 34 & 138 & 218 & 0.08 \\
\hline & Aoki (67) & 2009 & 3 & 29 & 40 & 7 & 53 & 30 & 0.01 \\
\hline
\end{tabular}

${ }^{\text {ap}} \mathrm{P}$-value for Hardy-Weinberg equilibrium in the control group.

Table II. ORs and 95\% CI for breast cancer and the p53 codon 72 polymorphism under different genetic models.

\begin{tabular}{llccccc}
\hline & & & & \multicolumn{3}{c}{ P-value } \\
\cline { 5 - 7 } Genetic model & Population & Pooled OR (95\% CI) & P-value & Heterogeneity & Begg's test & Egger's test \\
\hline Additive (Pro vs. Arg) & Asian & $1.016(0.958-1.077)$ & 0.539 & $<0.001$ & 0.948 & 0.889 \\
& Caucasian & $1.002(0.972-1.033)$ & 0.903 & $<0.001$ & 0.368 & 0.417 \\
& Others & $0.956(0.88-1.039)$ & 0.288 & $<0.001$ & 0.463 & 0.388 \\
& Overall & $1(0.975-1.026)$ & 0.993 & $<0.001$ & 0.356 & 0.357 \\
Recessive & Asian & $1.012(0.882-1.162)$ & 0.861 & 0.01 & 0.846 & 0.862 \\
(Pro/Pro vs. Arg-carriers) $)$ & Caucasian & $1.019(0.916-1.134)$ & 0.726 & $<0.001$ & 0.486 & 0.602 \\
& Others & $1.168(0.852-1.602)$ & 0.335 & $<0.001$ & 1 & 0.356 \\
& Overall & $1.029(0.95-1.115)$ & 0.479 & $<0.001$ & 0.602 & 0.37 \\
Dominant & Asian & $1.028(0.879-1.201)$ & 0.732 & 0.012 & 0.506 & 0.921 \\
(Pro-carriers vs. Arg/Arg) & Caucasian & $1.036(0.927-1.159)$ & 0.531 & 0.035 & 0.773 & 0.599 \\
& Others & $0.912(0.651-1.277)$ & 0.591 & 0.064 & 0.835 & 0.299 \\
Pro/Arg vs. Arg/Arg & Overall & $1.016(0.931-1.11)$ & 0.722 & 0.001 & 0.565 & 0.36 \\
& Asian & $1.027(0.887-1.188)$ & 0.725 & 0.082 & 0.916 & 0.931 \\
& Caucasian & $1.045(0.926-1.179)$ & 0.473 & 0.028 & 0.959 & 0.868 \\
& Others & $0.884(0.652-1.199)$ & 0.428 & 0.16 & 0.835 & 0.567 \\
Pro/Pro vs. Arg/Arg & Overall & $1.018(0.933-1.111)$ & 0.689 & 0.007 & 0.904 & 0.739 \\
& Asian & $1.035(0.843-1.272)$ & 0.74 & 0.001 & 0.248 & 0.829 \\
& Caucasian & $1.029(0.881-1.203)$ & 0.717 & $<0.001$ & 0.444 & 0.667 \\
& Others & $1.021(0.673-1.55)$ & 0.922 & 0.042 & 0.345 & 0.377 \\
& Overall & $1.028(0.916-1.153)$ & 0.639 & $<0.001$ & 0.188 & 0.385 \\
\hline
\end{tabular}

OR, odds ratio; CI, confidence interval.

\section{Materials and methods}

Publication search. PubMed was searched using the terms 'p53', 'polymorphism' and 'breast cancer' (the last search update was on May 1, 2012). The search was limited to English-language papers. Additional studies were identified by a manual search of the references of original studies. Of the studies with the same or overlapping data published by the same investigators, the most recent ones with the largest number of subjects were selected. Case-control studies containing available genotype frequencies of Arg72Pro were selected.

Statistical analysis. For the control group of each study, the allelic occurrence was considered and the observed genotype frequencies of the p53 codon 72 polymorphism were assessed 
for Hardy-Weinberg equilibrium using the $\chi^{2}$ test. The power of the correlation between the p53 codon 72 polymorphism and breast cancer risk was assessed by odds ratios (ORs) with 95\% confidence intervals (CIs). The risks of breast cancer for the GC and CC genotypes, relative to the wild-type GG homozygote were assessed; then, the risks of breast cancer for $\mathrm{GC} / \mathrm{CC}$ vs. GG and $\mathrm{CC}$ vs. GC/GG, and finally the supercilious dominant and recessive effects of the variant $\mathrm{C}$ allele were determined. Stratified analyses according to background, the source of controls and clinicopathological individuality were also performed. In considering the possibility of heterogeneity across the studies, an arithmetical test for heterogeneity was performed based on the Q-test. $\mathrm{P}<0.05$ for the Q-test was considered to indicate a lack of heterogeneity among the studies. The summary OR estimate of each study was calculated by the random effects model $(17,18)$. The potential for publication bias was examined by Begg's test and Egger's linear regression test. $\mathrm{P}<0.05$ was considered to indicate a statistically significant difference (19). All statistical analyses were performed with Stata software (version 9.0; Stata Corporation, College Station, TX, USA).

\section{Results}

Sixty-one case-control studies concerning the association between $\mathrm{p} 53$ codon 72 polymorphism and breast cancer were identified, which included 28,539 breast cancer cases and 32,788 controls. These data were used in a meta-analysis (Table I). The sharing of genotypes in the controls of all the studies was in agreement with Hardy-Weinberg equilibrium.

The results of the association between the p53 codon 72 polymorphism and breast cancer and the heterogeneity test are shown in Table II. The dominant model (Pro/Pro + Pro/Arg vs.Arg/Arg) demonstrated no significant association in Asian $(\mathrm{OR}=1.028,95 \% \mathrm{CI}=0.879-1.201$, $\mathrm{P}=0.732)$, Caucasian $(\mathrm{OR}=1.036,95 \% \mathrm{CI}=0.927-1.159$, $\mathrm{P}=0.531)$ or other subjects $(\mathrm{OR}=1.016,95 \% \mathrm{CI}=0.931-1.11$, $\mathrm{P}=0.722$ ).

\section{Discussion}

Given the important roles of p53 in multiple cellular functions, including gene transcription, DNA repair and apoptosis, it is biologically plausible that $\mathrm{p} 53$ polymorphisms may be associated with a risk of breast cancer (20). Human breast cancer is a disease with significant clinical consequences. The mechanism of breast cancer remains relatively unknown. Single nucleotide polymorphisms (SNPs) are used as a tool to investigate genetic variations and disease susceptibility.

Although a number of previous studies have reported a significant association between the $\mathrm{p} 53$ codon 72 polymorphism and breast cancer risk (21-34), others have identified no such association (35-39). In order to resolve this conflict, in the current study, a meta-analysis was conducted to examine the association between a commonly studied p53 polymorphism (codon 72 $\mathrm{G}<\mathrm{C}, \mathrm{Arg} 72 \mathrm{Pro}$ ) and breast cancer risk. A total of 28,539 breast cancer cases and 32,788 controls from 61 studies were included in the final analysis, to derive a more precise estimation of the presence or absence of this association. The polymorphism in codon 72 of the p53 gene was identified to have no association with breast cancer risk, either when the incorporated study populations were pooled or when they were subjected to a stratified analysis consistent with background or the source of controls. The latter result suggests that differences in genetic education, living environment and sources of controls do not impact any potential association between the p53 codon 72 polymorphism and breast cancer risk. Two assets of the current study were the large number of samples included and its failure to identify a significant association in any of the genetic models tested. Nevertheless, several limitations must be acknowledged. The controls in the studies were not homogenously defined, such that the control subjects in the different studies have varying risks of evolving breast cancer. Additionally, the results obtained in the present study are based on unadjusted estimations. A more accurate analysis could be conducted if more detailed individual data were available to allow it to be adjusted according to other covariates, including premenopause, postmenopause, smoking and drinking status, basal metabolic index, family history and environmental factors.

In conclusion, this meta-analysis, with a large model size, provides a strong indication that the p53 codon 72 polymorphism is not associated with breast cancer risk. Future studies should extend this investigation by incorporating other potential risk factors for breast cancer.

\section{Acknowledgements}

This work was supported by the National Science Foundation of China (No. 31170735,81260501), the Planned Science and Technology Project of Yunnan Province (2011DH011, 2012FB134).

\section{References}

1. Parkin DM, Bray F, Ferlay J and Pisani P: Estimating the world cancer burden: Globocan 2000. Int J Cancer 94: 153-156, 2001.

2. Yager JD and Davidson NE: Estrogen carcinogenesis in breast cancer. N Engl J Med 354: 270-282, 2006.

3. Veronesi U, Boyle P, Goldhirsch A, et al: Breast cancer. Lancet 365: 1727-1741, 2005.

4. Bartkova J, Lukas J, Strauss M and Bartek J: Cyclin D1 oncoprotein aberrantly accumulates in malignancies of diverse histogenesis. Oncogene 10: 775-778, 1995.

5. Porter-Jordan K and Lippman ME: Overview of the biologic markers of breast cancer. Hematol Oncol Clin North Am 8: 73-100, 1994

6. Callahan R, Cropp CS, Merlo GR, et al: Somatic mutations and human breast cancer. A status report. Cancer 69 (Suppl): 1582-1588, 1992.

7. Vogelstein B, Lane D and Levine AJ: Surfing the p53 network. Nature 408: 307-310, 2000.

8. Li Z, Ni M, Li J, Zhang Y, Ouyang Q and Tang C: Decision making of the p53 network: Death by integration. $J$ Theor Biol: Dec 3, 2010 (Epub ahead of print).

9. Brosh R and Rotter V: When mutants gain new powers: news from the mutant p53 field. Nat Rev Cancer 9: 701-713, 2009.

10. Bennett WP, Hussain SP, Vahakangas KH, Khan MA, Shields PG and Harris CC: Molecular epidemiology of human cancer risk: gene-environment interactions and p53 mutation spectrum in human lung cancer. J Pathol 187: 8-18, 1999.

11. Ravi R, Mookerjee B, Bhujwalla ZM, et al: Regulation of tumor angiogenesis by $\mathrm{p} 53$-induced degradation of hypoxia-inducible factor 1alpha. Genes Dev 14: 34-44, 2000.

12. Yuan A, Yu CJ, Luh KT, Kuo SH, Lee YC and Yang PC: Aberrant p53 expression correlates with expression of vascular endothelial growth factor mRNA and interleukin- 8 mRNA and neoangiogenesis in non-small-cell lung cancer. J Clin Oncol 20: 900-910, 2002. 
13. Mhawech P, Kinkel K, Vlastos G and Pelte MF: Ovarian carcinomas in endometriosis: an immunohistochemical and comparative genomic hybridization study. Int $\mathbf{J}$ Gynecol Pathol 21: 401-406, 2002.

14. Zhou Y, Li N, Zhuang W, et al: P53 codon 72 polymorphism and gastric cancer: a meta-analysis of the literature. Int J Cancer 121 1481-1486, 2007.

15. Harris N, Brill E, Shohat O, et al: Molecular basis for heterogeneity of the human p53 protein. Mol Cell Biol 6: 4650-4656, 1986.

16. Dumont P, Leu JI, Della Pietra AC III, et al: The codon 72 polymorphic variants of p53 have markedly different apoptotic potential. Nat Genet 33: 357-365, 2003.

17. Mantel $\mathrm{N}$ and Haenszel W: Statistical aspects of the analysis of data from retrospective studies of disease. J Natl Cancer Inst 22: 719-748, 1959

18. DerSimonian R and Laird N: Meta-analysis in clinical trials Control Clin Trials 7: 177-188, 1986.

19. Egger M, Davey Smith G, Schneider M and Minder C: Bias in meta-analysis detected by a simple, graphical test. BMJ 315 629-634, 1997.

20. Zhang Z, Wang M, Wu D, Wang M, Tong N, Tian Y and Zhang Z: P53 codon 72 polymorphism contributes to breast cancer risk: a meta-analysis based on 39 case-control studies. Breast Cancer Res Treat 120: 509-517, 2010.

21. Damin AP, Frazzon AP, Damin DC, et al: Evidence for an association of TP53 codon 72 polymorphism with breast cancer risk. Cancer Detect Prev 30: 523-529, 2006.

22. Själander A, Birgander R, Hallmans G, et al: p53 polymorphisms and haplotypes in breast cancer. Carcinogenesis 17: 1313-1316, 1996.

23. Kalemi TG, Lambropoulos AF, Gueorguiev M, Chrisafi S Papazisis KT and Kotsis A: The association of p53 mutations and p53 codon 72, Her 2 codon 655 and MTHFR C677T polymorphisms with breast cancer in Northern Greece. Cancer Lett 222: 57-65, 2005.

24. Akkiprik M, Sonmez O, Gulluoglu BM, Caglar HB, Kaya H, Demirkalem P, Abacioglu U, Sengoz M, Sav A and Ozer A: Analysis of p53 gene polymorphisms and protein over-expression in patients with breast cancer. Pathol Oncol Res 15: 359-368, 2009.

25. Buyru N, Tigli H and Dalay N: P53 codon 72 polymorphism in breast cancer. Oncol Rep 10: 711-714, 2003.

26. Gochhait S, Bukhari SI, Bairwa N, et al: Implication of BRCA2 $-26 \mathrm{G}>\mathrm{A} 5^{\prime}$ untranslated region polymorphism in susceptibility to sporadic breast cancer and its modulation by p53 codon 72 Arg>Pro polymorphism. Breast Cancer Res 9: R71, 2007.

27. Henríquez-Hernández LA, Murias-Rosales A, Hernández González A, et al: Gene polymorphisms in TYMS MTHFR, p53 and MDR1 as risk factors for breast cancer: A case-control study. Oncol Rep 22: 1425-1433, 2009.

28. Huang XE, Hamajima N, Katsuda N, Matsuo K, Hirose K Mizutani M, Iwata H, Miura S, Xiang J, Tokudome S and Tajima K: Association of p53 codon Arg72Pro and p73 G4C14-to-A4T14 at exon 2 genetic polymorphisms with the risk of Japanese breast cancer. Breast Cancer Res 10: 307-311, 2003.

29. Katiyar S, Thelma BK, Murthy NS, Hedau S, Jain N, Gopalkrishna V, Husain SA and Das BC: Polymorphism of the p53 codon $72 \mathrm{Arg} / \mathrm{Pro}$ and the risk of HPV type 16/18-associated cervical and oral cancer in India. Mol Cell Biochem 252: 117-124, 2003.

30. Li T, Lu ZM, Guo M, Wu QJ, Chen KN, Xing HP, Mei Q and Ke Y: p53 codon 72 polymorphism $(\mathrm{C} / \mathrm{G})$ and the risk of human papillomavirus-associated carcinomas in China. Cancer 95: 2571-2576, 2002

31. Sprague BL, Trentham-Dietz A, Garcia-Closas M, Newcomb PA, Titus-Ernstoff L, Hampton JM, Chanock SJ, Haines JL and Egan KM: Genetic variation in TP53 and risk of breast cancer in a population-based case control study. Carcinogenesis 28: 1680-1686, 2007

32. Wang-Gohrke S, Becher H, Kreienberg R, Runnebaum IB and Chang-Claude J: Intron 316 bp duplication polymorphism of p53 is associated with an increased risk for breast cancer by the age of 50 years. Pharmacogenetics 12: 269-272, 2002.

33. Weston A and Godbold JH: Polymorphisms of H-ras-1 and $\mathrm{p} 53$ in breast cancer and lung cancer: a meta-analysis. Environ Health Perspect 105 (Suppl 4): 919-926, 1997.

34. Zhang W, Jin MJ and Chen K: Association of $\mathrm{p} 53$ polymor-phisms and its haplotypes with susceptibility of breast cancer. Zhejiang Da Xue Xue Bao Yi Xue Ban 36: 561-566, 2007 (In Chinese).
35. Baynes C, Healey CS, Pooley KA, Scollen S, et al; SEARCH breast cancer study: Common variants in the ATM, BRCA1, BRCA2, CHEK2 and TP53 cancer susceptibility genes are unlikely to increase breast cancer risk. Breast Cancer Res 9: R27, 2007.

36. Mabrouk I, Baccouche S, El-Abed R, Mokdad-Gargouri R, Mosbah A, Saïd S, Daoud J, Frikha M, Jlidi R and Gargouri A: No evidence of correlation between $\mathrm{p} 53$ codon 72 polymorphism and risk of bladder or breast carcinoma in Tunisian patients. Ann NY Acad Sci 1010: 764-770, 2003

37. Khadang B, Fattahi MJ, Talei A, Dehaghani AS and Ghaderi A: Polymorphism of TP53 codon 72 showed no association with breast cancer in Iranian women. Cancer Genet Cytogenet 173: 38-42, 2007.

38. Schmidt MK, Reincke S, Broeks A, et al: Do MDM2 SNP309 and TP53 R72P interact in breast cancer susceptibility? A large pooled series from the breast cancer association consortium. Cancer Res 67: 9584-9590, 2007.

39. Tommiska J, Eerola H, Heinonen M, Salonen L, Kaare M, Tallila J, Ristimäki A, von Smitten K, Aittomäki K, Heikkilä P, Blomqvist $\mathrm{C}$ and Nevanlinna $\mathrm{H}$ : Breast cancer patients with p53 Pro72 homozygous genotype have a poorer survival. Clin Cancer Res 11: 5098-5103, 2005.

40. Kawajiri K, Nakachi K, Imai K, Watanabe J and Hayashi S: Germ line polymorphisms of 553 and CYP1A1 genes involved in human lung cancer. Carcinogenesis 14: 1085-1089, 1993.

41. Khaliq S, Hameed A, Khaliq T, et al: P53 mutations, polymorphisms, and haplotypes in Pakistani ethnic groups and breast cancer patients. Genet Test 4: 23-29, 2000.

42. Mahasneh AA and Abdel-Hafiz SS: Polymorphism of p53 gene in Jordanian population and possible associations with breast cancer and lung adenocarcinoma. Saudi Med J 25: 1568-1573, 2004.

43. Noma C, Miyoshi Y, Taguchi T, Tamaki Y and Noguchi S: Association of p53 genetic polymorphism (Arg72Pro) with estrogen receptor positive breast cancer risk in Japanese women. Cancer Lett 210: 197-203, 2004.

44. Siddique MM, Balram C, Fiszer-Maliszewska L, Aggarwal A, Tan A, Tan P, Soo KC and Sabapathy K: Evidence for selective expression of the $\mathrm{p} 53$ codon 72 polymorphs: implications in cancer development. Cancer Epidemiol Biomarkers Prev 14: 2245-2252, 2005.

45. Ma H, Hu Z, Zhai X, Wang S, Wang X, Qin J, Chen W, Jin G, Liu J, Gao J, Wang X, Wei Q and Shen H: Joint effects of single nucleotide polymorphisms in P53BP1 and p53 on breast cancer risk in a Chinese population. Carcinogenesis 27: 766-771, 2006.

46. Rajkumar T, Samson M, Rama R, Sridevi V, Mahji U, Swaminathan R and Nancy NK: TGF $\beta 1$ (Leu10Pro), p53 (Arg72Pro) can predict for increased risk for breast cancer in south Indian women and TGF $\beta 1$ Pro (Leu10Pro) allele predicts response to neo-adjuvant chemo radiotherapy. Breast Cancer Res Treat 112: 81-87, 2008.

47. Lum SS, Chua HW, Li H, Li WF, Rao N, Wei J, Shao Z and Sabapathy K: MDM2 SNP309 G allele increases risk but the $\mathrm{T}$ allele is associated with earlier onset age of sporadic breast cancers in the Chinese population. Carcinogenesis 29: 754-761, 2008.

48. Singh V, Rastogi N, Mathur N, Singh K and Singh MP: Association of polymorphism in MDM-2 and p53 genes with breast cancer risk in Indian women. Ann Epidemiol 18: 48-57, 2008.

49. Kazemi M, Salehi Z and Chakosari RJ: TP53 codon 72 polymorphism and breast cancer in northern Iran. Oncol Res 18: 25-30, 2009.

50. Song F, Zheng H, Liu B, Wei S, Dai H, Zhang L, Calin GA, Hao X, Wei Q, Zhang W and Chen K: An miR-502-binding site single-nucleotide polymorphism in the 3 '-untranslated region of the SET8 gene is associated with early age of breast cancer onset. Clin Cancer Res 15: 6292-6300, 2009.

51. Koh WP, Van Den Berg D, Jin A, Wang R, Yuan JM and Yu MC: Combined effects of MDM2 SNP309 and TP53 R72P polymorphisms, and soy isoflavones on breast cancer risk among Chinese women in Singapore. Breast Cancer Res Treat 130: 1011-1019, 2011.

52. Kara N, Karakus N, Ulusoy AN, Ozaslan C, Gungor B and Bagci H: P53 codon 72 and HER 2 codon 655 polymorphisms in Turkish breast cancer patients. DNA Cell Biol 29: 387-392, 2010.

53. Leu JD, Wang CY, Tsai HY, Lin IF, Chen RC and Lee YJ: Involvement of p53 R72P polymorphism in the association of MDM2-SNP309 with breast cancer. Oncol Rep 25: 1755-1763, 2011. 
54. Wang-Gohrke S, Rebbeck TR, Besenfelder W, et al: p53 germline polymorphisms are associated with an increased risk for breast cancer in German women. Anticancer Res 18: 2095-2099, 1998.

55. Papadakis EN, Dokianakis DN and Spandidos DA: p53 codon 72 polymorphism as a risk factor in the development of breast cancer. Mol Cell Biol Res Commun 3: 389-392, 2000.

56. Suspitsin EN, Buslov KG, Grigoriev MY, et al: Evidence against involvement of p53 polymorphism in breast cancer predisposition. Int J Cancer 103: 431-433, 2003.

57. Menzel HJ, Sarmanova J, Soucek P, Berberich R, Grünewald K, Haun M and Kraft HG: Association of NQO1 polymorphism with spontaneous breast cancer in two independent populations. Br J Cancer 90: 1989-1994, 2004.

58. Ohayon T, Gershoni-Baruch R, Papa MZ, Distelman Menachem T, Eisenberg Barzilai S and Friedman E: The R72P P53 mutation is associated with familial breast cancer in Jewish women. $\mathrm{Br} J$ Cancer 92: 1144-1148, 2005.

59. Garcia-Closas M, Kristensen V, Langerød A, et al: Common genetic variation in TP53 and its flanking genes, WDR79 and ATP1B2, and susceptibility to breast cancer. Int J Cancer 121: 2532-2538, 2007.

60. Franeková M, Zúbor P, Stanclová A, Dussan CA, Bohusová T, Galo S, Dobrota D, Kajo K, Péc M and Racay P: Association of p53 polymorphisms with breast cancer: a case-control study in Slovak population. Neoplasma 54: 155-161, 2007.

61. Johnson N, Fletcher O, Palles C, et al: Counting potentially functional variants in BRCA1, BRCA2 and ATM predicts breast cancer susceptibility. Hum Mol Genet 16: 1051-1057, 2007.

62. Cavallone L, Arcand SL, Maugard C, Ghadirian P, Mes-Masson AM, Provencher D and Tonin PN: Haplotype analysis of TP53 polymorphisms, Arg72Pro and Ins16, in BRCA1 and BRCA2 mutation carriers of French Canadian descent. BMC Cancer 8: 96, 2008.

63. Costa S, Pinto D, Pereira D, Rodrigues H, Cameselle-Teijeiro J, Medeiros R and Schmitt F: Importance of TP53 codon 72 and intron 3 duplication $16 \mathrm{bp}$ polymorphisms in prediction of susceptibility on breast cancer. BMC Cancer 8: 32, 2008.

64. De Vecchi G, Verderio P, Pizzamiglio S, et al: The p53 Arg72Pro and Ins16bp polymorphisms and their haplotypes are not associated with breast cancer risk in BRCA-mutation negative familial cases. Cancer Detect Prev 32: 140-143, 2008.

65. Nordgard SH, Alnaes GI, Hihn B, et al: Pathway based analysis of SNPs with relevance to 5-FU therapy: relation to intratumoral mRNA expression and survival. Int J Cancer 123: 577-585, 2008

66. Lång A, Palmebäck Wegman P and Wingren S: The significance of MDM2 SNP309 and p53 Arg72Pro in young women with breast cancer. Oncol Rep 22: 575-579, 2009.
67. Aoki MN, da Silva do Amaral Herrera AC, Amarante MK, do Val Carneiro JL, Fungaro MH and Watanabe MA: CCR5 and p53 codon 72 gene polymorphisms: implications in breast cancer development. Int J Mol Med 23: 429-435, 2009.

68. Hrstka R, Beranek M, Klocova K, Nenutil R and Vojtesek B: Intronic polymorphisms in TP53 indicate lymph node metastasis in breast cancer. Oncol Rep 22: 1205-1211, 2009.

69. Bisof V, Salihović MP, Narancić NS, Skarić-Jurić T, Jakić-Razumović J, Janićijević B, Turek S and Rudan P: TP53 gene polymorphisms and breast cancer in Croatian women: a pilot study. Eur J Gynaecol Oncol 31: 539-544, 2010.

70. Ebner F, Schremmer-Danninger E and Rehbock J: The role of TP53 and p21 gene polymorphisms in breast cancer biology in a well specified and characterized German cohort. J Cancer Res Clin Oncol 136: 1369-1375, 2010.

71. Alshatwi AA, Hasan TN, Shafi G, Alsaif MA, Al-Hazzani AA and Alsaif AA: A single-nucleotide polymorphism in the TP53 and MDM-2 gene modifies breast cancer risk in an ethnic Arab population. Fundam Clin Pharmacol 26: 438-443, 2012.

72. Alawadi S, Ghabreau L, Alsaleh M, Abdulaziz Z, Rafeek M, Akil N and Alkhalaf M: P53 gene polymorphisms and breast cancer risk in Arab women. Med Oncol 28: 709-715, 2011.

73. Weston A, Ling-Cawley HM, Caporaso NE, et al: Determination of the allelic frequencies of an L-myc and a p53 polymorphism in human lung cancer. Carcinogenesis 15: 583-587, 1994.

74. Helland A, Langerød A, Johnsen H, Olsen AO, Skovlund E and Børresen-Dale AL: p53 polymorphism and risk of cervical cancer. Nature 396: 530-531, 1998 .

75. Cox DG, Deer D, Guo Q, Tworoger SS, Hankinson SE, Hunter DJ and De Vivo I: The p53 Arg72Pro and MDM2-309 polymorphisms and risk of breast cancer in the nurses' health studies. Cancer Causes Control 18: 621-625, 2007.

76. Gaudet MM, Gammon, MD, Bensen JT, Sagiv SK, Shantakumar S, Teitelbaum SL, Eng SM, Neugut AI and Santella RM: Genetic variation of TP53, polycyclic aromatic hydrocarbon-related exposures, and breast cancer risk among women on Long Island, New York. Breast Cancer Res Treat 108: 93-99, 2008.

77. Denisov EV, Cherdyntseva NV, Litvyakov NV, et al: TP53 mutations and Arg72Pro polymorphism in breast cancers. Cancer Genet Cytogenet 192: 93-95, 2009. 